\title{
A Comparative Study on University Students' Rational and Experiential Thinking Styles in Terms of Faculty, Class Level and Gender Variables
}

\author{
Yemliha Coşkun \\ Department of Educational Sciences, Kahramanmaraş Sutcu Imam University, Turkey
}

Copyright(C2018 by authors, all rights reserved. Authors agree that this article remains permanently open access under the terms of the Creative Commons Attribution License 4.0 International License

\begin{abstract}
The aim of the study was to investigate the university students' thinking styles. The research was a descriptive study in the screening model. The study was carried out with 382 students from the faculties of physical education and sports, education, science and letters, theology, business administration, engineering, forestry and agriculture at Kahramanmaras Sutcu Imam University during the spring semester of 2016-2017 academic year. They were selected by convenience sampling method. 'Personal Information Form' and 'Rational-Experiential Thinking Styles Inventory' were used as data collection tools. The research data were analyzed through use of SPSS 15.0. The study has concluded that university students' rational and experiential thinking levels moderate in other words, students use both styles of thinking. The female and male students' rational thinking styles are similar; however, female students score higher on the experimental thinking style. It was also found that there was no significant difference between thinking style and class level and faculties.
\end{abstract}

Keywords Thinking Styles, Rational and Experiential Skills Styles, University Students

\section{Introduction}

Thought is the activity of acquiring new knowledge and results by passing through all kinds of data immersed in the brain during the perception process with its own internal flows. In other words, thinking refers to bring together all the perceptions and events of the human brain in itself. Thinking is defined as all the perceptions of the brain, making comparisons within itself, separating, consolidating, conceiving the forms, while thought implies the results obtained from them [1]. Thinking is a distinctive feature that separates human beings from the others. The most important thing in such a process is likely that individuals can think qualitatively and use different thinking processes and skills in this regard [2]. These processes, which are rendered as thinking styles, are significant factors that shape and understand human behaviors.

Human behaviors can only be understood by both knowing the factors that stimulate the behavior and understanding how the individual interprets it. Otherwise, it will be difficult to understand people showing different reactions to similar events. This phenomenon requires the awareness of the individuals' cognitive processes as well as the influence of environmental factors in understanding human behaviors [3].

Recognizing the reasons for which two people in the same environment have different impressions and knowing the characteristics of individuals having very different forms of information processing will make the interpretation of behavior easier [4]. Expressing his views on this subject, George Kelly considers the cognitive structures we use to interpret and predict events as 'personal constructs', meaning that no one's personal structures resemble others, and that no one has organized mental structures in a similar way. He also linked the reason why we demonstrate different behaviors to the use of different constructs [4]. These cognitive structures which are expressed as schemas enable us to organize and process information consistently. In this way, our knowledge employs a well-structured cognitive structure rather than the form of disjointed pieces of information [4]. The integrity of these schemes, which evolve on the basis of the difference of life experience, is a significant factor that leads to the formation of individual thinking styles. Thinking styles considered as the outward reflection of thinking processes in different ways [5] are the approaches and tendencies that individuals exhibit as a result of mental processes against various problems, events, phenomena and variables. 
Thinking styles are closely related to how we learn and operate knowledge. We all have a profile where we vary in the amount of each style; we are not dependent on any profile and we can change our styles in order to comply with different tasks and situations. Although individuals often differ across their thinking styles, it is common for classifications regarding thinking styles to be regarded as high or low in terms of these characteristics. So to speak, individuals can have various ways of thinking styles towards a problem; however, they use some of them predominantly depending on special cases. Therefore, individuals can attain high and low levels in the level of thinking considered in classifications related to thinking [6]. Besides, it is worth mentioning this distinction, that is, style is a way of thinking not an ability. It is the path that an individual chooses so as to use their abilities. Hence, the styles are not classified as good or bad, but they just have different characteristics. It is of up most importance to distinguish style and ability.

Ability refers to what an individual can do or shows how well someone can do something. Style, on the other hand, expresses how people prefer to use their abilities and how they like to do something. On social occasions, ability is sometimes confused with thinking styles, leading to the fact that individual differences resulting from the styles are actually perceived as though they came from talents. Undoubtedly, abilities are essential to achieve success in the educational process and career, but skills do not represent the whole and not fully explain the performance of the school.

The success in school and business life explains only a part of the difference between individuals and talents. Thinking styles may be one of the sources of unexplained variability in terms of clarifying the remaining differences. How individuals choose to think is as significant as how well they think $[7,8,9,10]$.

Upon examining the relevant literature, there seems to be various theories trying to explain people's ways of thinking [11], one of which is cognitive-experiential self-theory. This theory explains that people's mental functions work in a parallel and interactive manner, as rational and experiential information processing systems.

Cognitive-experiential self-theory is a psychodynamic global theory of personality that substitutes a different kind of unconscious processing for the Freudian unconscious. Unlike the maladaptive Freudian unconscious, the unconscious of cognitive-experiential self-theory is an adaptive, associative learning system. Although the systems are independent in the sense that they operate by different rules, they nevertheless are highly interactive. The two systems usually operate in synchrony and produce compromises between them, but sometimes they conflict with each other, resulting in what are commonly referred to as conflicts between the heart and the head [12]. Epstein [12] states that there is no superiority between the two systems: Which system is superior? At first thought, it might seem that it must be the rational system. After all, the rational system, with its use of language, is a much more recent evolutionary development than is the experiential system, and it is unique to the human species. Moreover, it is capable of much higher levels of abstraction and complexity than is the experiential system, and it makes possible planning, long term delay of gratification, complex generalization and discrimination, and comprehension of cause-and-effect relations. These attributes of the rational system have been the source of humankind's remarkable scientific and technological achievements. Moreover, the rational system can understand the operation of the experiential system, whereas the reverse is not true. On the other side of the coin, carefully consider the following question: If you could have only one system, which would you choose? Without question, the only reasonable choice is the experiential system. You could exist with an experiential system without a rational system, but you could not exist with only a rational system. Fortunately, there is no need to choose between the systems. Each has its advantages and disadvantages, and the advantages of one can offset the limitations of the other. Where we do have a choice is in improving our ability to use each and to use them in a complementary manner. The differences between the Experiential and Rational System are described as follows.

Table 1. Comparison of the Experiential and Rational Systems

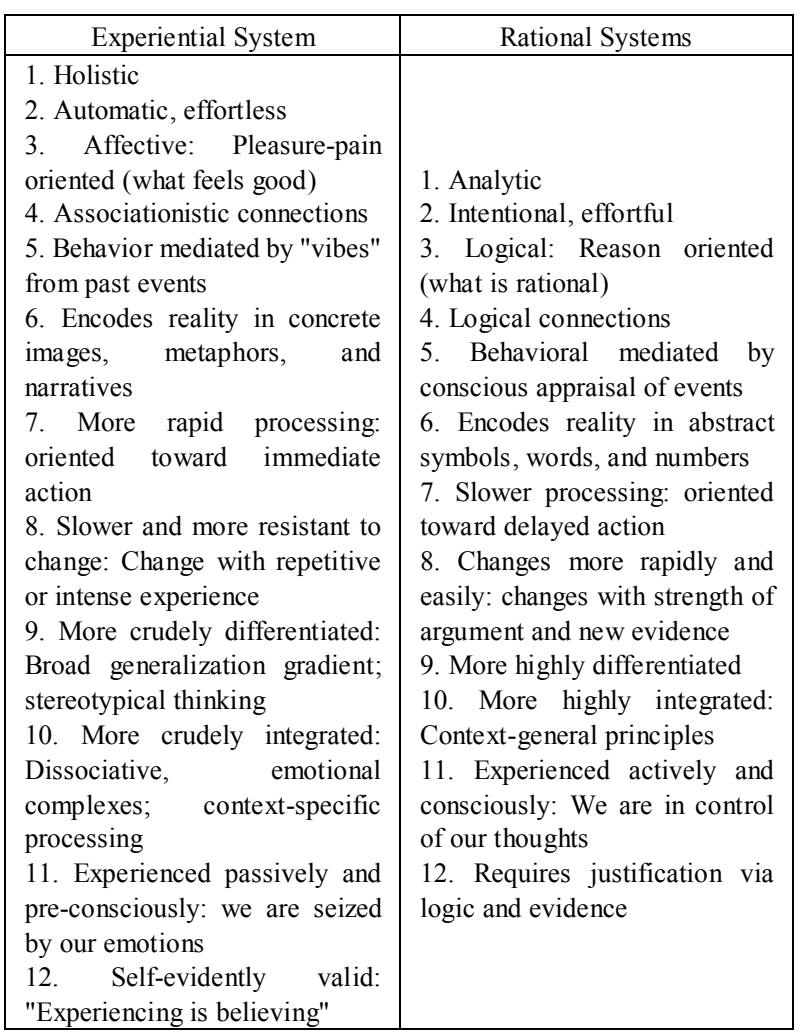

(Epstein, 1991: as cited in Epstein, Pacini, Denes-Raj \& Heier, 1996) [24]

Thinking styles that can be applied to all areas of life are functional in learning and teaching. One of the basic 
knowledge of education and teaching is to educate and train individuals by taking their differences into account [13]. In this reality, it is necessary to provide a suitable teaching environment for students' thinking styles since the contribution of the students' thinking styles is so significant in achieving the desired success during teaching and learning processes [14]. In this regard, the most basic point is a student's awareness of his/her own thinking styles. First, it will make the student feel confident about what $\mathrm{s} /$ he likes to do. If the student fails in what he or she has done, this may not because of the lack of skill and ability. S/he will develop alternatives at the point of reaching meaningful solution through thinking and understanding that job requirements may not overlap with his/her own thinking style [14].

Besides, it is essential increase the ability of students to move from one style to another through education as the situation requires. Teachers, on the other hand, must be trained in order to use thinking styles flexibly. This flexibility can be achieved by defining various tasks for the teacher or the students and asking them which way of thinking will be most effective in achieving each task. In this way, thinking ability of the students and teachers with different styles develops. Because individuals have a style profile with different amounts from each style, they are not fixed to any profile, and they can change depending on different kinds of tasks and situations $[15,7]$.

Still, teachers and students sometimes ignore thinking styles by misinterpreting failure as a loss of ability resulting from the inconsistency in teaching and learning style. When teachers do not have awareness of thinking styles and when they teach and evaluate students who think and learn with certain styles, this may cause other students to be disadvantaged and fail. Teachers, however, are considered to be in a situation where students' performance is expected to increase when they have different thinking and teaching methods [7].

Depending on this reality, research on which type of teaching method preferred by students with different thinking styles will provide important contributions to the individualization of education and to making education-training processes more effective [14]. Hence, numerous studies have been conducted with university students related to their thinking styles $[16,10,17,18,19$, 20, 21, 22, 23]. As Stenberg [15] points out, this phenomenon should be attached great importance by educators since any topic can be taught in any compatible style manner, and students look for learning activities that are compatible with the styles they prefer; besides, the course content, teaching methods and techniques need to be structured within this reality.

Thus, it is important to determine the profiles of university students in terms of their thinking styles besides other factors in order to achieve success in university education. In this sense, this research has been carried out to determine the thinking styles of university students.
Depending on the main research question "What are the thinking styles of university students?", answers to the following questions have been sought:

1. What are the thinking styles of university students?

2. Do university students' thinking styles differ across gender?

3. Do university students' thinking styles differ across class level?

4. Do university students' thinking styles differ across faculty?

\section{Materials and Methods}

This study, which examines the thinking styles of university students, is a descriptive study in the screening model.

\subsection{Sample and Procedure}

After the ethics approval of the research, it was realized with 3rd and 4th grade students who read in 8 different faculties at Sütçü İmam University in 2016-2017 academic year. 394 students were included in the application, but were excluded from the survey because they were not eligible to score 12 forms in the study. Therefore, the research was conducted with 382 students.

The research sample holds a total of 382 third and fourth grade university students who study at the faculties of physical education and sports, education, science and letters, theology, business administration, engineering, forestry and agriculture at Kahramanmaraş Sütçü İmam University during of 2016 and 2017 academic year. They were selected through convenience sampling method.

Table 2. Demographic Characteristics of the Participants

\begin{tabular}{ccc}
\hline Demographic Characteristics & $\mathrm{N}$ & $\%$ \\
\hline Gender & & \\
\hline Female & 233 & 61,0 \\
\hline Male & 149 & 39,0 \\
\hline Faculty /Vocational High School & & \\
\hline Physical Education and Sports & 40 & 10,5 \\
\hline Education & 49 & 12,8 \\
\hline Science-Letters & 90 & 23,6 \\
\hline Theology & 38 & 9,9 \\
\hline Business Administration & 42 & 11,0 \\
\hline Engineering & 30 & 7,9 \\
\hline Forestry & 28 & 7,3 \\
\hline Agriculture & 65 & 17,0 \\
\hline Class Level & & \\
\hline 3rd & 229 & 59,9 \\
\hline 4th & 153 & 40,1 \\
\hline
\end{tabular}

Among the participants, $61.0 \%$ were female and $39.0 \%$ were male. Considering faculties, $10.5 \%$ of them are physical education and sports, $12.8 \%$ are education, $23.6 \%$ are science and letters, $9.9 \%$ are theology, $11.0 \%$ 
are business administration, $7.9 \%$ are engineering, 7.3\% are forestry and $17.0 \%$ are agriculture faculty students. $59.9 \%$ of the participants are in the 3 rd class and $40.1 \%$ are in the 4th class level.

\section{2. Data Collection Tools}

This research has used "Personal Information Form" developed by the researcher, and "Rational-Experiential Thinking Styles İnventory' developed by Epstein et al. [24] and translated into Turkish by Buluş [11].

\subsubsection{Personal Information Form}

Personal information form developed by the researcher in order to collect data about the independent variables includes 3 questions in total (gender, faculty and class level).

\subsubsection{Rational-Experiential Thinking Styles Inventory}

'Rational-Experiential Thinking Styles Inventory' was developed by Epstein et al. [24] in order to measure individual differences in the intuitive-experiential and analytical-rational thinking styles that people use in knowledge processing. The tool, the Turkish adaptation of which was done by Buluş [11], includes 29 items and 2 sub-scales. The first sub-scale, consisting of 17 items, measures rational thinking, while the other is intuitive belief subscale and includes 12 items. It measures confidence level of the individuals in emotions and first impressions in information processing and actions. The internal consistency reliability coefficients have been determined as .75 and .80 for the cognition requirement and intuitive belief, respectively. Being a five-point likert type, the items of the tool are ranged from "completely wrong" to "completely correct". Thus, the score range of the cognition requirement factor ranges from 17 to 85 , while that of the intuitive belief factor ranges from 12 to 60 . The cognition requirement of the scale is defined as the analytical-rational thinking style, whereas the intuitive belief is described as the intuitive-experiential thinking style.

\section{3. Analysis of Data}

Data were analyzed through SPSS 15.0 packet statistical program. Arithmetic mean, frequency, standard deviation and percentage distributions were calculated in order to determine participants' socio-demographic characteristics, and thinking styles. Independent samples t-test to reveal the difference in thinking styles in terms of gender and class level. Besides, ANOVA test was used to determine the difference in thinking styles depending on faculty. Significance level was taken as 0.05 .

\section{Findings}

The arithmetic mean and standard deviation values of the university students' rational-experiential thinking styles levels are presented in Table 3.

Table 3. Arithmetic Mean and Standard Deviations of Students' Values and Happiness Levels

\begin{tabular}{|c|c|c|c|}
\hline Variables & $\mathrm{N}$ & $\overline{\mathrm{X}}$ & $\begin{array}{c}\text { Standard } \\
\text { Deviation }\end{array}$ \\
\hline $\begin{array}{c}\text { 1. Rational Thinking } \\
\text { Styles Level }\end{array}$ & 382 & 55,85 & 10,35 \\
\hline $\begin{array}{c}\text { 2. Experiential Thinking } \\
\text { Styles Level }\end{array}$ & 382 & 43,93 & 8,22 \\
\hline
\end{tabular}

Table 3 depicts that the students have 55,85 arithmetic mean scores and 10,35 standard deviations of their rational thinking styles level; 43,93 arithmetic mean scores and 8,22 standard deviations of their experiential thinking styles level. Accordingly, it is likely to mention that the rational and experiential thinking levels of the students are moderate. In other words, students use both styles of thinking.

Table 4. Independent Group t-test Results of Rational and Experiential Thinking Level of University Students in terms of Gender

\begin{tabular}{|c|c|c|c|c|c|c|c|}
\hline & Gender & $\mathrm{N}$ & $\overline{\mathrm{X}}$ & Standard Deviation & $\mathrm{df}$ & $\mathrm{t}$ & $\mathrm{p}$ \\
\hline \multirow{2}{*}{ 1. Rational Thinking Level } & Female & 233 & 55.09 & 9.84 & \multirow{2}{*}{380} & \multirow{2}{*}{-1.79} & \multirow{2}{*}{.073} \\
\hline & Male & 149 & 57.04 & 11.03 & & & \\
\hline \multirow{2}{*}{ 2. Experiential Thinking Level } & Female & 233 & 44.97 & 8.36 & \multirow{2}{*}{380} & \multirow{2}{*}{3.11} & \multirow{2}{*}{$.002 *$} \\
\hline & Male & 149 & 42.31 & 7.76 & & & \\
\hline
\end{tabular}

$\mathrm{p}<0.05^{*}$

Table 5. Independent Group t-test Results of Rational Experiential Thinking Level of University Students in terms of Class Level

\begin{tabular}{|c|c|c|c|c|c|c|c|}
\hline & Class Level & $\mathrm{N}$ & $\overline{\mathrm{X}}$ & Standard Deviation & df & $\mathrm{t}$ & $\mathrm{p}$ \\
\hline \multirow{2}{*}{ 1. Rational Thinking Level } & $3 \mathrm{rd}$ & 229 & 55,10 & 10,53 & \multirow{2}{*}{380} & \multirow{2}{*}{-1.73} & \multirow{2}{*}{, 084} \\
\hline & 4 th & 153 & 56,97 & 10,00 & & & \\
\hline \multirow{2}{*}{ 2. Experiential Thinking Level } & $3 \mathrm{rd}$ & 229 & 43,92 & 7,87 & \multirow{2}{*}{380} & \multirow{2}{*}{-.033} & \multirow{2}{*}{,974 } \\
\hline & 4 th & 153 & 43,95 & 8,74 & & & \\
\hline
\end{tabular}

As can be seen from Table 4, students' rational thinking styles scores are examined in terms of gender was not a statistically significant difference between male and female students $(\mathrm{t}=-1,79 ; \mathrm{p}>.01)$. In other words, the female and 
male student's rational thinking styles are similar. However, a significant difference has been noted between students' experimental thinking styles scores $(\mathrm{t}=3,11 ; \mathrm{p}<.01)$, depending upon gender in favor of female students.

As can be seen Table 5 , no significant difference has been noted between students' rational $(t=-1,73 ; p>.01)$ and experiential $(\mathrm{t}=-.033 ; \mathrm{p}>.01)$ thinking styles depending upon class level. In other words, 3rd and 4th class students' rational and experiential thinking styles are similar.

Table 6. Variance Analysis Results of Students' Rational Thinking Levels in terms of Faculty

\begin{tabular}{|c|c|c|c|c|c|c|c|c|}
\hline Faculties & $\mathrm{N}$ & $\overline{\mathrm{X}}$ & $\begin{array}{c}\text { Standard } \\
\text { Deviation }\end{array}$ & $\begin{array}{c}\text { Source of } \\
\text { Variance }\end{array}$ & $\begin{array}{c}\text { Sum of } \\
\text { Squares }\end{array}$ & $\mathrm{df}$ & $\begin{array}{c}\text { Mean } \\
\text { Square }\end{array}$ & $\mathrm{F}$ \\
\hline $\begin{array}{c}\text { Physical Education and } \\
\text { Sports }\end{array}$ & 40 & 54.37 & 10.93 & $\begin{array}{c}\text { Between } \\
\text { Groups }\end{array}$ & 1044.88 & 7 & 149.26 & 1.40 \\
\hline Education & 49 & 57.57 & 10.39 & Within Groups & 39792.90 & 374 & 106.39 \\
\hline Science-Letters & 90 & 55.34 & 10.34 & Total & 40837.79 & 381 & \\
\hline Theology & 38 & 57.94 & 11.34 & & & & & \\
\hline $\begin{array}{c}\text { Business } \\
\text { Administration }\end{array}$ & 42 & 54.57 & 9.65 & & & & & \\
\hline Engineering & 30 & 58,03 & 9.17 & & & & & \\
\hline Forestry & 28 & 52.10 & 9.97 & & & & & \\
\hline Agriculture & 65 & 56.38 & 10.24 & & & & & \\
\hline Total & 382 & 55.85 & 10.35 & & & & & \\
\hline
\end{tabular}

As can be seen from Table 6, students rational thinking style scores are examined in terms of faculty, was not a statistically significant difference between different faculties $(F=1.40 ; p>.05]$. In other words, different faculties students' rational thinking styles are similar.

As can be seen from Table 7, students experiential thinking style scores are examined in terms of faculty, was not a statistically significant difference between different faculties $(F=1.59 ; \mathrm{p}>.05]$. In other words, different faculties students' experiential thinking styles are similar.

Table 7. Variance Analysis Results of Students' Experiential Thinking Levels in terms of Faculty

\begin{tabular}{|c|c|c|c|c|c|c|c|c|c|}
\hline Faculties & $\mathrm{N}$ & $\overline{\mathrm{X}}$ & $\begin{array}{c}\text { Standard } \\
\text { Deviation }\end{array}$ & $\begin{array}{c}\text { Source of } \\
\text { Variance }\end{array}$ & $\begin{array}{c}\text { Sum of } \\
\text { Squares }\end{array}$ & $\mathrm{df}$ & Mean Square & $\mathrm{F}$ & $\mathrm{p}$ \\
\hline $\begin{array}{c}\text { Physical Education and } \\
\text { Sports }\end{array}$ & 40 & 45.30 & 7.14 & $\begin{array}{c}\text { Between } \\
\text { Groups }\end{array}$ & 748.58 & 7 & 106.94 & 1.59 & .134 \\
\hline Education & 49 & 45.10 & 9.17 & Within Groups & 25025.90 & 374 & 66.91 & \\
\hline Science-Letters & 90 & 44.08 & 8.80 & Total & 25774.49 & 381 & & & \\
\hline Theology & 38 & 42.89 & 8.68 & & & & & & \\
\hline $\begin{array}{c}\text { Business } \\
\text { Administration }\end{array}$ & 42 & 41.73 & 8.67 & & & & & & \\
\hline Engineering & 30 & 41,30 & 7.91 & & & & & & \\
\hline Forestry & 28 & 46.21 & 6.60 & & & & & & \\
\hline Agriculture & 65 & 44.27 & 7.10 & & & & & & \\
\hline Total & 382 & 43.93 & 8.22 & & & & & \\
\hline
\end{tabular}

\section{Results, Discussion and Recommendations}

It is paramount for teachers and students to understand the concept of the effects of thinking styles in the process of learning in order to provide more effective learning and to be able to develop thinking styles with the reality that the styles are not fixed but flexible in terms of learning material [14]. Based on this significance, the research conducted to determine university students' thinking styles has revealed that the students have medium level of thinking style in terms of both cognitive and experiential thinking styles. This indicates that students are not dominantly dependent on any thinking style, and that they use both cognitive and experiential thinking styles in their thinking preferences. No significant difference has been identified across gender in terms of cognitive thinking styles, while a significant difference has been found in experiential thinking styles in favor of female students, meaning female students are more likely to prefer the experiential thinking styles compared to males. On the other hand, no significant difference has been found in terms of the thinking styles of the $3^{\text {rd }}$ and $4^{\text {th }}$ grade students. This result, which can be regarded as an expected situation, indicates that the thinking styles of the students are similar as they are in the last stages of the education process. The fact that the students from different faculties do not significantly vary across their thinking styles, and those who study at different faculties have nearly similar average is considered an unexpected result. When the characteristics of the faculties, the differences in the theoretical and practical content of the courses and the 
skills developed by the students are taken into consideration, a difference is expected among different faculties in terms of thinking styles, but no difference has been identified. This may be due to the fact that the lessons are theoretical, the students' achievement is mostly evaluated through theoretical knowledge, and the use of the different applications required by the courses in the faculties is inadequate. All these results make it difficult to emphasize a distinctive difference among thinking styles in terms of departments. The results have also been suggested that:

İt would be beneficial to consider this situation in the teaching period depending on the finding that the experiential thinking styles of the male and female students are different.

Students' academic achievement can be improved so that they are informed about thinking styles.

For instructors to prepare appropriate learning environments, students may need to be aware and educated about thinking styles.

The formation of thinking styles may be influenced by other factors such as individual psychological characteristics, cultural factors or social environment. In this sense, it would be helpful to explain these results and interpretations with researches to be carried out with other samples with different demographic characteristics.

\section{REFERENCES}

[1] Benazus, H. 2011. Düşünce:İnsana Tanınan Ayrıcalık. Bizim Kitaplar, İstanbul.

[2] Demir, Ö, \& Erginsoy-Osmanoğlu, D. (2013). Lise öğrencilerinin düşünme stillerininçeşitli değişkenleracısından incelenmesi. Eğitim Bilimleri Araştırmaları Dergisi, 3(1), 165- 184.

[3] Buluş, M. (2000). Öğretmen adaylarında yükleme karmaşıklığı, düşünme stilleri ve bilişsel tutarlılık tercihinin bazı psiko sosya lözellikler ve akademik başarı çerçevesinde incelenmesi. Yayınlanmamış doktora tezi, Dokuz Eylül Üniversitesi Eğitim Bilimleri Enstitüsü, İzmir.

[4] Burger, J. M. (2006). Kişilik (Çev. İ. D. Erguvan Sarığlu) KaknüsYayıncılık, İstanbul

[5] Yildızlar, M. (2010). Farklı kültürlerden gelen öğretmen adaylarının düşünme stilleri/ Thinking styles of candidate teachers who come from different cultures, Hacettepe Üniversitesi, Eğitim Fakültesi Dergisi (H. U. Journal of Education), 39, 383-393.

[6] Sünbül, A. M. (2004). Düşünme stilleri ölçeğinin geçerlik v egüvenirliği. Eğitim ve BilimDergisi, 29 (132), 25-42.

[7] Sternberg, R. J. (1994). Allowing for thinking styles, Educational Leadership. 52 (3), 36-40.

[8] Sternberg, R. J. (2009). DüşünmeStilleri (Çev. Güngör, E.). RedhouseYayınc1lı, İstanbul.
[9] Grigeronko, E. L., Sternberg, R. J. (1997). Styles of thinking, Abilities, and academic performance. Exceptional Children, 63(3), 295-312.

[10] Zhang, L. F. (2002b). Thinking styles and the big five personality traits, Educational Psychology, 22(1), 17-31.

[11] Buluş, M. (2003). Rasyonel- Yaşantısal düşünme stilleri ölçeği'nin güvenirlik ve geçerliği (Reliability and validity of rational-experiential thinking styles inventory), Ege Eğitim Dergisi, 3(1), 133-138.

[12] Epstein, S. (2003). Cognitive-experiential self-theory of personality. In Millon, T., \& Lerner, M. J. (Eds), Comprehensive Handbook of Psychology, Volume 5: Personality and Social Psychology (pp. 159-184). Hoboken, NJ: Wiley \& Sons.)

[13] Oflar, Y. \& Yıldız, K. (2010). İlköğretim okulu öğretmenlerinin düşünme stilleri, International Journal of Field Education, 2 (2), 20-37.

[14] Sevinç, M. vePalut, B. (2008). Öğretmen düşünme stilleri ölçeğinin Türkçeye uyarlanması ve geçerlik güvenirlikçalışması, Boğaziçi Üniversitesi Eğitim Dergisi, 25(2), 1-19).

[15] Sternberg, R. J. (1990). Thinking styles: Keys to understanding student performance. Phi Delta Kappan, 71(5), 366-371.

[16] Zhang, L. F. (2002a). Thinking styles and cognitive development, The Journal of Genetic Psychology, 2002, 163 (2), 179-195.

[17] Zhang, L. F. (2004a). Thinking styles: university students' preferred teaching styles and their conceptions of effective teachers, The Journal of Psychology, 138(3), 233-252.

[18] Zhang, L. F. (2004b). Do university students' thinking styles matter in their preferred teaching approaches? Personality and Individual Differences, 37(8), 1551-1564.

[19] Sofo, F. \& Berzins, M. (2009). North, south, least, best: geographical location and the thinking styles of Italian university students, Australian Journal of Adult Learning, 49(2), 269-293.

[20] Moutsios-Rentzos. A., \& Simpson, A. (2010). The thinking styles of university mathematics students. Actadidactica Napocensia, 3 (4), 1-10.

[21] Abdi, A. (2012). A study on the relationship of thinking styles of students and their critical thinking skills. Procedia-Social and Behavioral Sciences, 47, 1719-1723.

[22] Fan, J. (2016). The role of thinking styles in career decision making self-efficacy among university students. Think Skills Creativity. 20, 63-73. DOI: 10.1016/j.tsc.2016.03.001.

[23] Alipoura, A., Akhondya, N., Aerab-sheybanib, K. (2012). Relationship between handedness and thinking styles in female and male students. Procedia - Social and Behavioral Sciences, 32, $22-28$.

[24] Epstein, S., Pacini, R., Denes-Raj, V. \& Heier, H. (1996). Individual differences in intuitive-experiential and analytical-rational thinking styles. Journal of Personality and Social Psychology, 71(2), 390-405. 